\title{
AIR SCORE ASSESSMENT FOR ACUTE APPENDICITIS
}

\author{
Avaliação do escore de AIR para apendicite aguda
}

Bruno VON-MÜHLEN, Orli FRANZON, Murilo Gamba BEDUSCHI, Nicolau KRUEL, Daniel LUPSELO

From Hospital Regional de São José (Regional Hospital of São José), São José, SC, Brazil

HEADINGS - Acute appendicitis. AIR score. C-reactive protein.
ABSTRACT - Background: Acute appendicitis is the most common cause of acute abdomen. Approximately $7 \%$ of the population will be affected by this condition during full life. The development of AIR score may contribute to diagnosis associating easy clinical criteria and two simple laboratory tests. Aim: To evaluate the score AIR (Appendicitis Inflammatory Response score) as a tool for the diagnosis and prediction of severity of acute appendicitis. Method: Were evaluated all patients undergoing surgical appendectomy. From 273 patients, 126 were excluded due to exclusion criteria. All patients were submitted o AIR score. Results: The value of the C-reactive protein and the percentage of leukocytes segmented blood count showed a direct relationship with the phase of acute appendicitis. Conclusion: As for the laboratory criteria, serum C-reactive protein and assessment of the percentage of the polymorphonuclear leukocytes count were important to diagnosis and disease stratification.

\section{Correspondence: \\ Bruno Von-Mühlen \\ E-mail: brunomuhlen@yahoo.com.br \\ Financial source: none \\ Conflicts of interest: none \\ Received for publication: $17 / 03 / 2015$ \\ Accepted for publication: 02/06/2015}

DESCRTORES: Apendicite aguda. Escore AIR. Proteína C reativa.
RESUMO - Racional: A apendicite aguda é a causa mais frequente de abdome agudo. Aproximadamente $7 \%$ da população será acometida por ela durante a vida. O desenvolvimento do escore Appendicitis Inflammatory Response (AIR) contribui para o diagnóstico através de critérios clínicos de fácil aplicabilidade e dois exames laboratoriais simples. Objetivo: Avaliar os critérios de AIR como ferramenta para o diagnóstico e predição da gravidade dos casos de apendicite aguda. Método: Foram avaliados todos os pacientes submetidos à apendicectomia. Do total de 273 pacientes 126 foram excluídos devido ao não cumprimento dos critérios de inclusão. Todos foram submetidos ao escore. Resultados: Quanto ao escore de AIR todos os pacientes do estudo se alocaram nos subgrupos de moderada $(65,3 \%)$ e alta probabilidade $(34,7 \%)$ para apendicite aguda. O valor da proteína C reativa e a porcentagem de segmentados no leucograma apresentaram relação direta com a fase da apendicite aguda. Conclusão: A dosagem sérica da proteína $C$ reativa e avaliação do percentual de segmentados no leucograma mostraram ser importantes para o diagnóstico e a estratificação da fase evolutiva da doença.

\section{INTRODUCTION}

A cute appendicitis is the most common cause of acute abdomen. Approximately $7 \%$ of the population will be affected by this condition during full life ${ }^{7}$. It most often occurs in adolescence and in the $20^{\prime} \mathrm{s}$, in a $3: 2^{2}$ man-woman ratio. The acute appendicitis continues to be an important cause of morbidity in the population when its diagnosis is late or only known in developed stages of diffuse peritonitis ${ }^{9}$

The inflammation of the vermiform appendix happens mainly due to the obstruction of its lumen ${ }^{3}$. From the anatomopathologic point of view, the acute appendicitis is classified as: catarrhal, phlegmonous, gangrenous and perforated. These categories represent the evolutionary stages of the disease ${ }^{8}$.

Pain in the abdomen is the main and most frequent symptom of acute appendicitis, with classic migration from periumbilical or epigastric to location in the right iliac fossa in $75 \%$ of patients. It may occasionally be reported in other places depending on the position occupied by the cecal appendix.

In most cases it is associated with muscular defense, nausea, vomit and low fever.

These symptoms generally aggravate as the disease progresses. The diagnosis is eminently clinical, being associated with laboratory and image exams in case of diagnostic uncertainty ${ }^{4}$.

The development of AIR score contributes to diagnosis because through associating easily applicable clinical criteria and two simple laboratory tests it is attributed the score which classifies the patients regarding the probability of diagnosis ${ }^{5}$.

The main aim of this study was to assess the AIR criteria as a tool for diagnosis and predicting the seriousness of the acute appendicitis cases.

METHODS

The project was approved by the local Research Ethics Commission. A retrospective cohort has been performed at Hospital Regional de São José, São José, SC, Brazil. A 
monthly data collection was made, which helped review the medical records and the medical exams of patients who underwent appendectomy between July of 2013 and July of 2014 .

A hundred and twenty-six out of 273 patients who underwent appendectomy did not meet the inclusion criteria (absence of physical exam data in medical record and absence of CBC (complete blood count) and/or CRP (C - reactive protein), leaving out 147 patients. The only included were the ones who had conditions to satisfy the full AIR score criteria.

As criteria for assessment, were used the data from the physical examination (abdominal pain in the right iliac fossa, degree of abdominal defense, fever, vomit) and lab criteria from CBC and dosage of CRP to stablish stratification of AIR score (Table1)

A data base was built in the SPSS program (Statistic Package for Social Sciences) in its version 17.0. The program made possible to analyze the information and build graphs, tables and descriptive statistics.

The descriptive analysis was performed from the absolute simple frequencies, percentage and descriptive measurements (mean, medium, standard variation and maximum/minimum values). A test t of Student was used for the continuous variables and a test $U$ of Mann-Whiney for independent samples. The fixed significance level was $5 \%(p<0,05)$.

TABLE 1 - Appendicitis Inflammatory Response (AIR) score

\begin{tabular}{|c|c|}
\hline Diagnosis & score \\
\hline Vomit & 1 \\
\hline Pain in RIF & 1 \\
\hline Abdominal Defense & \\
\hline low & 1 \\
\hline Mild & 2 \\
\hline Severe & 3 \\
\hline Temperature $>38,5$ C & 1 \\
\hline Segmented Neutrophils & \\
\hline $70-84 \%$ & 1 \\
\hline$>85 \%$ & 2 \\
\hline Leukocytes & 1 \\
\hline$>10.0-14.9 \times 109 / /$ & 2 \\
\hline$>15.0 \times 109 / /$ & \\
\hline CRP & 1 \\
\hline $10-49 \mathrm{~g} / \mathrm{l}$ & 2 \\
\hline$>50 \mathrm{~g} / \mathrm{l}$ & \\
\hline
\end{tabular}

AIR: sum 0-4=low probability; sum 5-8=mild probability; sum 9-12=high probability; RIF=Right Iliac Fossa; $C R P=C$ - reactive protein.
RESULTS

There was predominance of males $(65,3 \%)$ over females $(34,7)$. The age varied from 16 to 85 , with an average of 34,3 and standard variation of 14,5 (Table 2).

A 2,8 days of development time was observed, with standard variation of 2,7 , with minimum of one and maximum of 15 days.

TABLE 2 - Complete description according to age, days of development and AIR score $(n=147)$

\begin{tabular}{|c|c|c|c|}
\hline Description & Age & Days of development & AIR score \\
\hline Mean & 34,3 & 2,8 & 7,7 \\
\hline Medium & 31 & 2 & 7 \\
\hline Standard Variation & 14,5 & 2,7 & 1,7 \\
\hline Min & 16 & 1 & 5 \\
\hline Max & 87 & 15 & 12 \\
\hline Number of Patients & 147 & 147 & 147 \\
\hline IC & 2,3 & 0,4 & 0,3 \\
\hline
\end{tabular}

The AIR score criteria was on average 7,7 with mean of 7 , its minimum value of 5 and maximum of 12 . All were placed in subgroups as mild $(65,3 \%)$ and high probability $(34,7 \%)$ for acute appendicitis.

Pain in the right iliac fossa was observed in 140 patients $(95,3 p<0,0001)$ as variables in the AIR criteria.

Vomit was reported in $51,7 \%$ and the axillary temperature went up beyond $38,5^{\circ} \mathrm{C}$ in just $27,9 \%$ of the patients $(p<0,0001)$. The abdominal defense was described as low (44,2\%), mild $(35,4 \%)$ and intense $(20,4 \%)$.

As for the development of acute appendicitis, all have been stratified during intraoperative procedure. Regarding the aspect of the cecal appendix, it was considered stage 1 catarrhal, stage 2 suppurated, stage 3 gangrenous and stage 4 perforated. Stage 2 was the most prevalent $(37,4 \%)$.

When the percentage of segmented neutrophils was associated with the acute appendicitis phase, it demonstrated that the phase 1 had $85 \%$ smaller value of segmented neutrophils in $95 \%$ of cases $(p<0,05)$.

When the stage 4 appendicitis was analyzed, was noticed an inversion in tendency with a higher than $85 \%$ more segmented neutrophils predominance in $60 \%$ of patients (Table 3 ).

By analyzing the CRP value, in initial cases - stage 1 , the CRP remained between $10-49$ in $95 \%$ of cases, and above 50 in $60 \%$ of stage 4 cases.

TABLE 3 - Reference of appendicitis stage with percentage of segmented neutrophils in WBC and CRP

\begin{tabular}{|c|c|c|c|c|c|c|c|c|c|c|c|c|}
\hline \multirow{2}{*}{\multicolumn{2}{|c|}{ Appendicitis phase }} & \multicolumn{2}{|c|}{ Stage 1} & \multicolumn{2}{|c|}{ Stage 2} & \multicolumn{2}{|c|}{ Stage 3} & \multicolumn{2}{|c|}{ Stage 4} & \multicolumn{2}{|c|}{ Total } & \multirow[b]{2}{*}{ p } \\
\hline & & $\mathrm{n}$ & $\%$ & $\mathrm{n}$ & $\%$ & $\mathrm{n}$ & $\%$ & $\mathrm{n}$ & $\%$ & $n$ & $\%$ & \\
\hline \multirow{2}{*}{$\begin{array}{l}\text { Segmented } \\
\text { Neutrophils }\end{array}$} & $70 \%$ to $84 \%$ & 18 & $95 \%$ & 35 & $64 \%$ & 22 & $67 \%$ & 16 & $40 \%$ & 91 & $62 \%$ & \multirow{2}{*}{0,001} \\
\hline & $>85 \%$ & 1 & $5 \%$ & 20 & $36 \%$ & 11 & $33 \%$ & 24 & $60 \%$ & 56 & $38 \%$ & \\
\hline \multirow{2}{*}{ CRP } & 10 to 49 & 18 & $95 \%$ & 49 & $89 \%$ & 18 & $55 \%$ & 16 & $40 \%$ & 101 & $69 \%$ & \multirow{2}{*}{$<0,001$} \\
\hline & $>50$ & 1 & $5 \%$ & 6 & $11 \%$ & 15 & $45 \%$ & 24 & $60 \%$ & 46 & $31 \%$ & \\
\hline
\end{tabular}

$\mathrm{CRP}=\mathrm{C}$ reactive protein

TABELA 4 - Relation between AIR score with the stage of appendicitis, percentage of segmented neutrophils and CRP

\begin{tabular}{|c|c|c|c|c|c|c|c|c|}
\hline \multirow{2}{*}{\multicolumn{2}{|c|}{ Total score }} & \multicolumn{2}{|c|}{ Mild } & \multicolumn{2}{|c|}{ High } & \multicolumn{2}{|c|}{ Total } & \multirow{2}{*}{$p$} \\
\hline & & $n$ & $\%$ & $\mathrm{n}$ & $\%$ & $\mathrm{n}$ & $\%$ & \\
\hline \multirow{2}{*}{ Segmented neutrophils } & $70 \%$ to $84 \%$ & 75 & $78 \%$ & 16 & $31 \%$ & 91 & $62 \%$ & \multirow{2}{*}{$<0,001$} \\
\hline & $>85 \%$ & 21 & $22 \%$ & 35 & $69 \%$ & 56 & $38 \%$ & \\
\hline \multirow{4}{*}{ Stage of appendicitis } & Phase 1 & 18 & $19 \%$ & 1 & $2 \%$ & 19 & $13 \%$ & \multirow{4}{*}{$<0,001$} \\
\hline & Phase 2 & 41 & $43 \%$ & 14 & $27 \%$ & 55 & $37 \%$ & \\
\hline & Phase 3 & 21 & $22 \%$ & 12 & $24 \%$ & 33 & $22 \%$ & \\
\hline & Phase 4 & 16 & $17 \%$ & 24 & $47 \%$ & 40 & $27 \%$ & \\
\hline \multirow{2}{*}{ CRP } & 10 to 49 & 85 & $89 \%$ & 16 & $31 \%$ & 101 & $69 \%$ & \multirow{2}{*}{$<0,001$} \\
\hline & $>50$ & 11 & $11 \%$ & 35 & $69 \%$ & 46 & $31 \%$ & \\
\hline
\end{tabular}

$\mathrm{CRP}=\mathrm{C}$ reactive protein; $\mathrm{AIR}=\mathrm{Appendicitis} \mathrm{Inflammatory} \mathrm{Response}$ 
When was connected the AIR score to the appendicitis evolutionary stage, was noticed that a mild score relates to the initial stages ( 1 and 2 ) in $62 \%$ of cases, while the high probability score was related to developed stages (3 and 4) in $71 \%$ (Table 4).

\section{DISCUSSION}

All patients who underwent appendectomy were stratified by the AIR criteria as mild (65,3\%) and high probability (34,3\%) for acute appendicitis, which made possible to infer that the patients assessed in the emergency suffering from abdominal pain and that had been stratified as low probability, in fact did not need surgical intervention.

The pain in the right iliac fossa is the main symptom for acute appendicitis and in this sample, it was present in $95,2 \%$ of patients $s^{6,7,11}$.

Patients with score forhigh probability had statistically significant chance of showing more developed stages of acute appendicitis ${ }^{1}$.

When criteria were analyzed in a isolated manner, as previously described by other authors, was noticed that CRP and segmented neutrophils show direct relation with the acute appendicitis stage. CRP was below 50 in patients in stage 1 and segmented neutrophils below $85 \%$ in $95 \%$ of the cases, and in stage 4, CRP was above 50 and segmented neutrophils above $85 \%$ in $60 \%$ of patients ${ }^{10}$.

\section{CONCLUSION}

The AIR score is useful for diagnosing acute appendicitis. The serum CRP and assessment of percentage of segmented neutrophils in WBC are important in the diagnosis and stratification of evolutionary stage of the disease.

\section{REFERENCES}

1. Andersson R. Meta-analysis of the clinical and laboratory diagnosis of appendicitis. Br J Surg 2004; 91(1):28-37.

2. Borges PSG, Nogueira LMC, Neto GHF. Validação do escore de Alvarado no diagnóstico de apendicite aguda em crianças e adolescentes no Instituto Materno Infantil de Pernambuco - IMIP. Rev Bras Saúde Matern. Infant.2003; 3(4):439-445.

3. Brenner AS, Santin JVN, Frederico BT, Valarini RR. Apendicectomia em pacientes com idade superior a 40 anos: análise dos resultados de 217 casos. Rev bras. colo-proctol. 2006 Jun26(2): 128-132.

4. Carvalho BR, Diogo-Filho A, Fernandes C, Barra CB. Leucograma, proteína $C$ reativa, alfa-1 glicoproteína ácida e velocidade de hemossedimentação na apendicite aguda. Arq Gastroenterol. 2003 Mar; 40 (1):25-30.

5. Castro SM, Ünlü C, Steller EP, van Wagensveld BA, Vrouenraets BC. Evaluation of the Appendicitis Inflammatory Response Score for Patients with Acute Appendicit. World J Surg (2012) 36:1540-1545

6. Fischer CA, Pinho MSL, Ferreira S, Milani CAC, van Santen $C R$, Marquardt RA. Apendicite aguda: existe relação entre o grau evolutivo, idade e o tempo de internação. Rev. Col. Bras. Cir. 2005; 32( 3 ): 136-138.

7. Franzon O, Picolli MC, Neves TT, Volpato MG. Apendicite aguda: análise institucional no manejo perioperatório. ABCD Arq Bras Cir Dig Artigo Original 2009;22(2):72-75

8. Freitas RG, Pitombo MB, Maya MCA, Leal P.R. Apendicite Aguda. Revista do Hospital Universitário Pedro Ernesto, UERJ. Vol. 8, N. 1 Jan/Jun - 2009.

9. Goldman L, Ausiello, Cecil, D. Tratado de Medicina Interna. Tradução de Ana kemper et al. Rio de Janeiro Elsivier, 2005.

10. Goulart GS, Silvério GS, Moreira MB, Franzon O. Achados principais de exames laboratoriais no diagnóstico de apendicite aguda: uma avaliação prospectiva. ABCD Arq Bras Cir Dig 2012;25(2):88-90

11. Reis JMO, Lucatto TM, Reis Júnior WB. Diagnóstico e tratamento de 300 casos de apendicite aguda em crianças e adolescentes atendidos em um hospital universitário. Revista Médica de Minas Gerais 2008; 18(1): 11-15. 